\title{
Selected Problems in Using Round Timber in Building Structures
}

\section{LOKAJ Antonín ${ }^{1, a}$, KLAJMONOVÁ Kristýna ${ }^{2, b, ~ * ~}$}

${ }^{1,2}$ Department of Building Structures, Faculty of Civil Engineering, VŠB-Technical University of Ostrava, Ludvíka Podéště 1875/17, 708 33, Ostrava, Czech Republic

\author{
aantonin.lokaj@vsb.cz, ${ }^{b}$ kristyna.klajmonova@vsb.cz
}

Keywords: round, timber, building, structures, joint, steel, bolt.

\begin{abstract}
The content of this paper are possibilities of using round timber in various public facilities structures (e.g. children's playgrounds) and in engineering constructions (e.g. watchtowers, bridges and footbridges). Specific problems of designing round timber structures, mainly in joints, are presented here.
\end{abstract}

\section{Introduction}

Over the last decades the use of round timber constructions has increased significantly. Current trends support the use of ecological constructions. These structures are environment friendly and emphasize the use of natural and renewable building materials. Round timber structures (milled or simply stripped of bark) meet all these requirements. Various view-towers, pedestrian bridges, visitor centers in natural parks or in the ZOO, playground equipment and other landscape structures are built from round timber logs. In all the cases the structural systems were used as an interesting architectural feature.

\section{Types of Timber Structures Made of Round Timber}

At present children's playgrounds, which are made of natural round timber (see Fig. 1) or shaped round timber (see Fig. 2), are very popular.
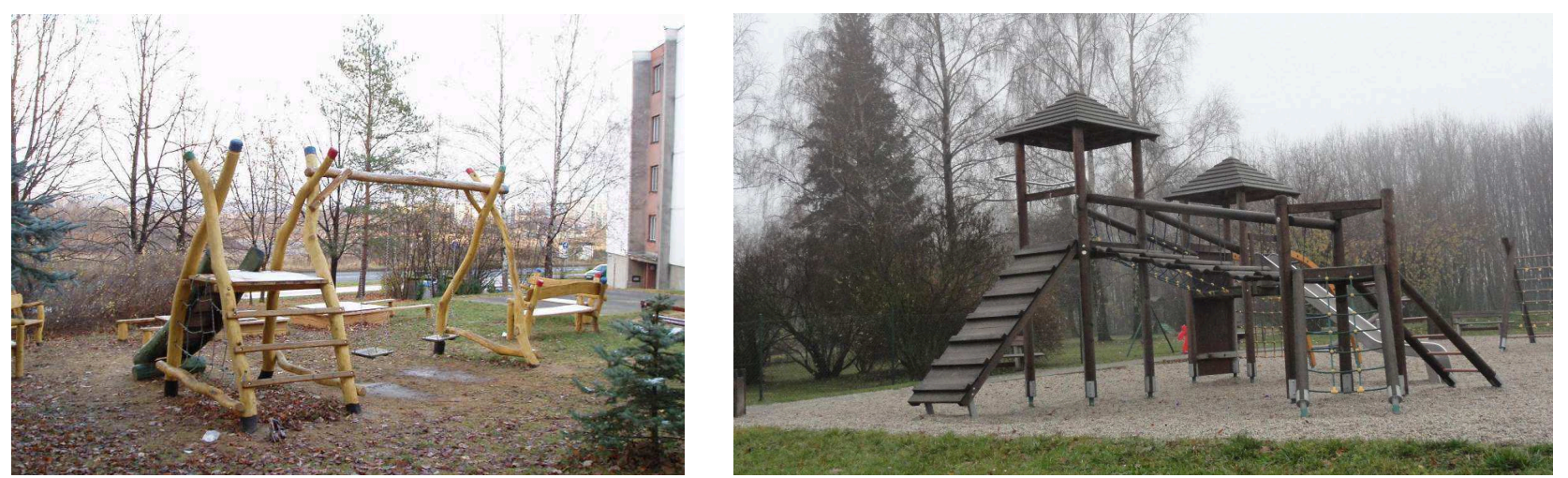

Fig. 1 Playground made of natural round timber (left)

Fig. 2 Playground made of shaped round timber (right)

Round timber can be used also in timber footbridges constructions and bridges with smaller span. Example of a footbridge made of round timber in Orlová is in Fig. 3. 

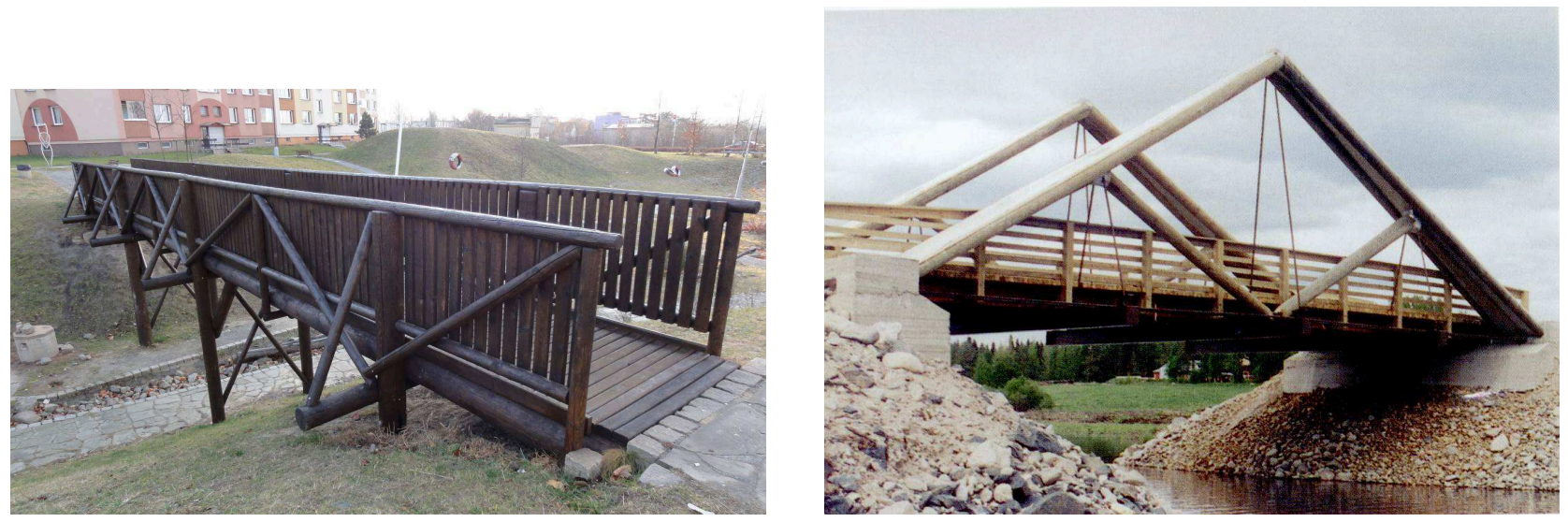

Fig. 3 Footbridge in Orlová (left)

Fig. 4 Lehmilahti bridge (Finland), photo - [1] (right)

Example of timber bridge made of round timber with $19 m$ span is in Fig. 4.

The tallest round timber view-tower in central Europe was built in Lázně Bohdaneč in the Czech Republic; the height of the tower is almost $53 \mathrm{~m}$ (see [2] and Fig. 5). The tower was opened in 2011. The whole tower was made of natural round timber (spruce) and bolted joints with slotted-in steel plates.

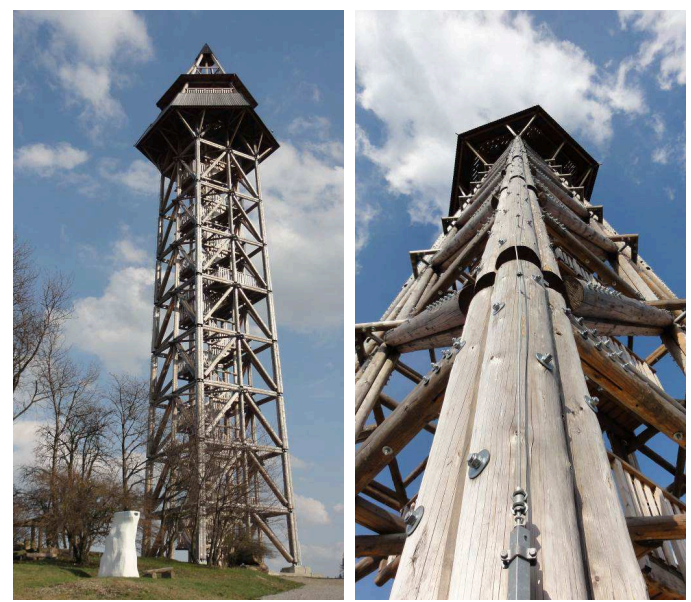

Fig. 5 View tower near Lázně Bohdaneč

Several interesting view-towers were built near Uherské Hradiště. One was built in combination of round and sawn timber and bolted joints with slotted-in steel plates (see Fig. 6). Another one was built only from round timber and bolted joints (see Fig. 7).

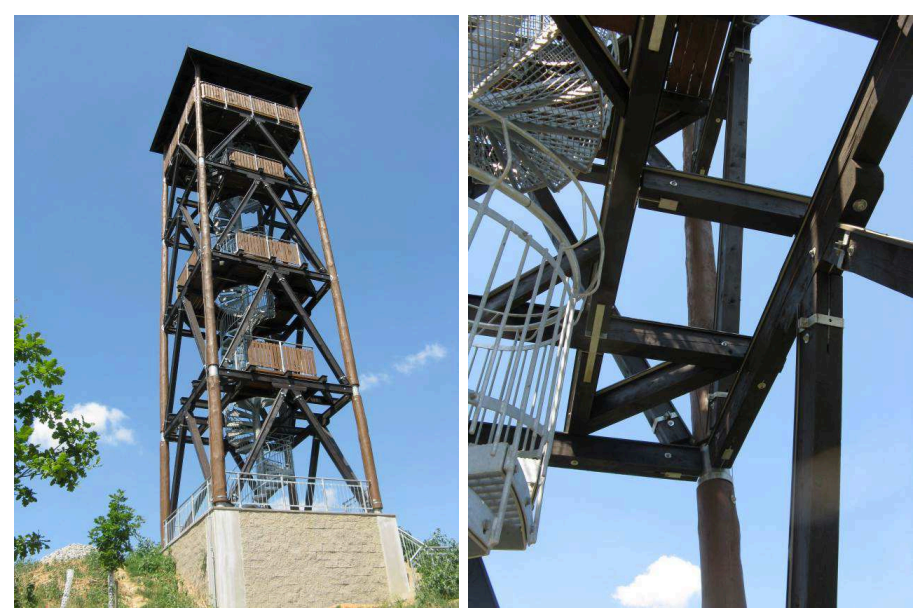

Fig. 6 View tower in Polešovice 


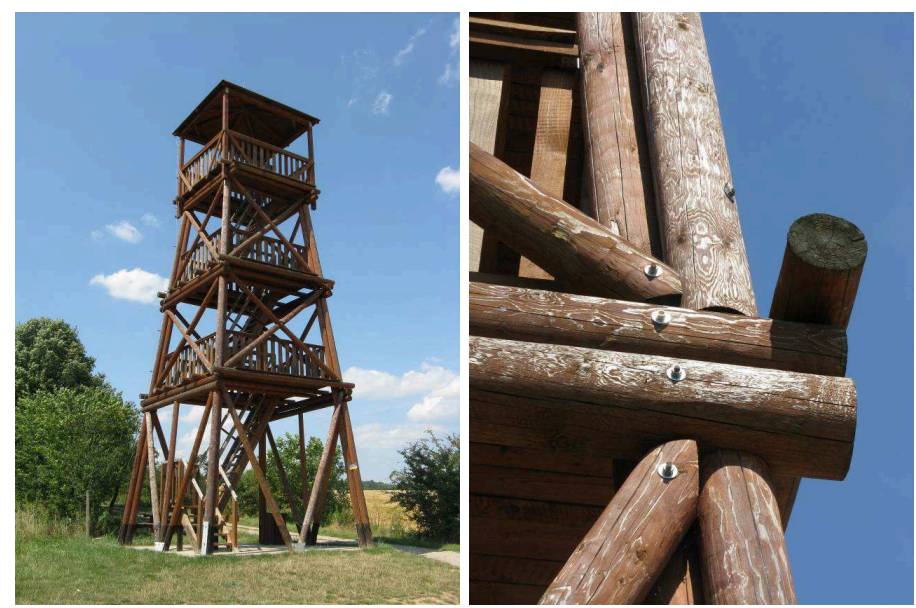

Fig. 7 View tower in Vlčnov

\section{Types of Joints}

Several types of joints can be used in round timber structures, e.g. carpenter joints, nails, screws, steel bounds, but nowadays bolted joints or bolted joints with slotted-in steel plates (see Fig. 8) are most popular.

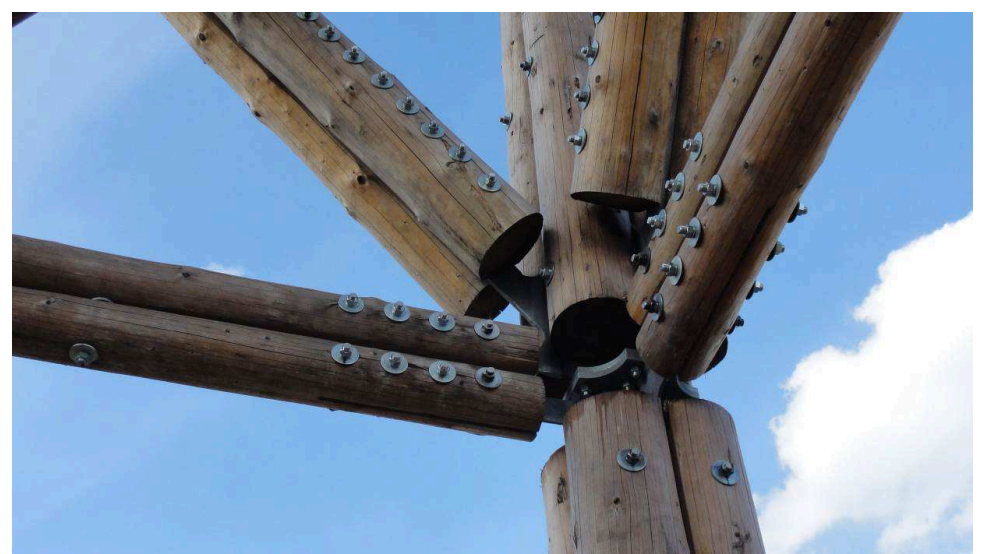

Fig. 8 Example of a round timber bolted joint with slotted-in steel plates

\section{Research of Bolted Joints with Slotted in Steel Plates Carrying Capacity}

Element connections are often made from bolts with slotted in steel plates, especially for truss structures. These connections are the weakest part of structures. Mechanical reinforcement possibilities of round timber bolted joints were researched and tested in a laboratory of the Faculty of Civil Engineering. However, at present there is little information available about timber joints reinforcement, and the design standards (e.g. [3]) give few guidelines. For more information - see $[4,5]$.

\section{Test Samples}

All the test samples were made of spruce wood. A few nondestructive tests were carried out before the start of static tests in the press. The test samples were weighed on a laboratory scale, their moisture and dimensions were measured. The thickness of the annual rings and the slope of grain were also measured. The density was determined on the basis of measured values. The average moisture was $12,4 \%$. The average value of apparent density reached $480 \mathrm{~kg} / \mathrm{m}^{3}$ (with standard deviation $88 \mathrm{~kg} / \mathrm{m}^{3}$ ).

It was necessary to adapt the dimensions of the test specimens to dimensional possibilities of the laboratory machinery. Thus, the specimen length was $450 \mathrm{~mm}$, and the diameter was $120 \mathrm{~mm}$. The bolts made of high strength steel (category 8.8) were used. The connection plates were made of steel 
S235. The plates had a thickness of $8 \mathrm{~mm}$, length of $290 \mathrm{~mm}$ and width $80 \mathrm{~mm}$. Holes in steel plates and timber with diameter $22 \mathrm{~mm}$, respectively, $20 \mathrm{~mm}$ were used. The holes distance to the free end in the timber was $140 \mathrm{~mm}$; in the steel $50 \mathrm{~mm}$. Several specimens were made without reinforcement. The others were reinforced in a various way (with special washers, screws, steel plates and nails etc. - see Fig. 10 ).

\section{Course of Tests}

The specimens were subjected to a simple tension test (see Fig. 9). The tension force (samples were loaded parallel to the grain) was increased gradually. The displacement rate choice of the press jaws was optimal because the failure of all the specimens appeared in a time-boundary $300 \pm 120 \mathrm{sec}$, which corresponds to the current European standard [3]. Test parameters were the same for all the specimens.

At first, unreinforced specimens were tested. The average value of carrying capacity in tension was $67 \mathrm{kN}$ (with standard deviation $15 \mathrm{kN}$ ). All the testing specimens were damaged by splitting. The embedment underneath the bolts grew during loading, and the crack was initiated. During the next loading, the crack grew rapidly and uncontrolled until the final damage. The sample failures were caused by reaching the critical tensile stress perpendicular to the grain.
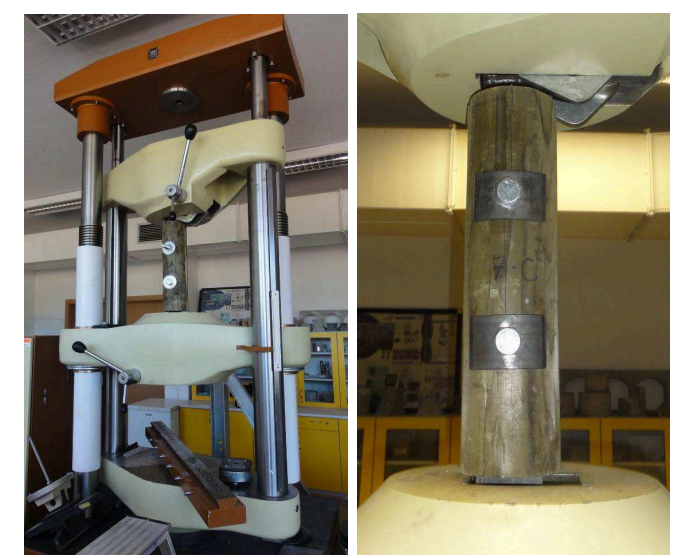

Fig. 9 Laboratory press (left), a sample with modified washers in the press (right).

\section{Reinforcement}

The reinforcement design was based on the first series test results. The reinforcement relates to the timber in the connection area. The challenge is to avoid the splitting failure mechanisms. The reinforcement is supposed to have two basic effects: tensile stresses perpendicular to the grain are transferred and the embedding capacity of the reinforced timber area increases. Several different reinforcement methods were tested - applying modified washers, common wood screws (one or two under each bolt), BOVA plates and applying steel bands.
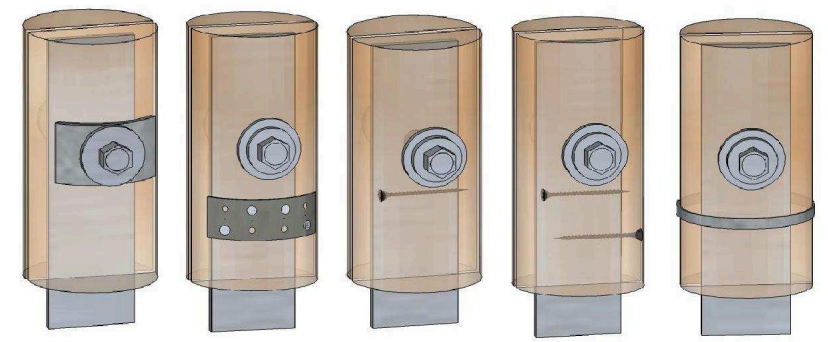

Fig. 10: Reinforcement methods: (from left) modified washers, BOVA plate, one screw, two screws, steel band 
For the modified washers approach, the washers were made from a steel plate with thickness $8 \mathrm{~mm}$, category S235. The dimensions of these plates were $60 \mathrm{~mm}$ to $100 \mathrm{~mm}$. Holes with a diameter $22 \mathrm{~mm}$ were used. The washers had been rounded to fit tightly to round timber sample, and the wood in the area of the bolt was clamped firmly. BOVA plate is a steel plate with a thickness of $2 \mathrm{~mm}$ and dimensions of 40 to $120 \mathrm{~mm}$, provided with holes for nails. The plate was fastened to a sample with four nails. Plates were bent according to shape of the sample.

For the common wood screws approach, the tested screws had a diameter of $5 \mathrm{~mm}$ and length of $90 \mathrm{~mm}$. One or two screws were located under each bolt (in the direction of loading). The screws were oriented perpendicular to the grain. The last method is to tighten the end of the samples with a steel band. The band has a thickness of $0,9 \mathrm{~mm}$ and width $9 \mathrm{~mm}$.

\section{Results}

The average carrying capacity in tension of the samples with modified washers was $72,7 \mathrm{kN}$. Cracking and subsequent growth were decreased. In the case of samples with screws, during the sample testing, no failure due to the crack occurrence was observed. Displacement was increased up to the failure. All the observed failures were caused by the plug shear. The average carrying capacity in tension of these samples was 72,4 $\mathrm{kN}$ (with standard deviation $19 \mathrm{kN}$ ). Decreased rates of cracking and subsequent growth were observed on the reinforced samples. Furthermore, plug shear failures were observed in the case of reinforcement by applying wood screws.

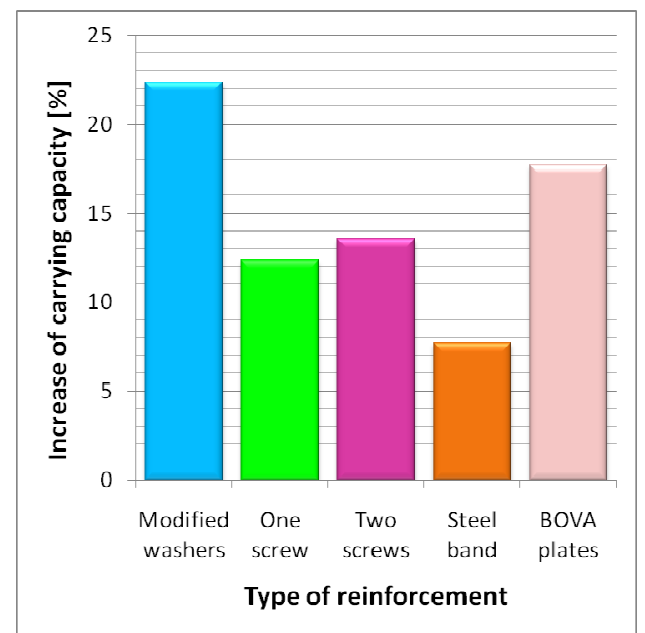

Fig. 11: Comparison of effectivity of reinforcement methods

Fig. 11 shows that reinforcing by means of the modified washers and BOVA plates demonstrates the highest increase in carrying capacity. In terms of implementation simplicity, reinforcing using two screws appears to be the most effectual.

\section{Summary}

The reinforced samples were able to absorb around $20 \%$ more of the pressure before cracking than the unreinforced ones. Both of the reinforcing methods are economically profitable due to the usage of affordable parts. However, as the number of samples is small, the presented results are prone to a statistical error. Due to the relatively high carrying capacity dispersion of the round timber and the bolted joints with the slotted - in plates it is reasonable to consider using some of the fully probabilistic methods e.g. [6, 7, 8] for the reliable and safe design and assessment of this type of structures and joints. 
Acknowledgement. This outcome has been achieved with funds of Conceptual development of science, research and innovation assigned to VŠB-Technical University of Ostrava by Ministry of Education Youth and Sports of the Czech Republic.

\section{References}

[1] Educational materials for designing and testing of timber structures - TEMTIS, Leonardo da Vinci pilot project CZ/06/B/F/PP/168007, 2008.

[2] B. Straka, M. Šmak, Joints with steel elements in timber structures (in Czech). In Proceedings of international conference Dřevostavby 2011. Volyně 20. and 21. 4. 2011. Pp. 151-158. ISBN 97880-86837-33-8.:

[3] Eurocode 5: Design of timber structures - Part 1-1: General - Common rules and rules for buildings. 2004.

[4] I. Smith et al. (2003) Fracture and Fatigue in Wood. John Wiley \& Sons, England.

[5] A. Lokaj, K. Klajmonová, Round timber bolted joints exposed to static and dynamic loading, Wood Research, Vol. 59, Issue 3/2014, pp. 439-448, July 2014.

[6] A. Lokaj, P. Marek, Simulation-based reliability assessment of timber structures, in: Proceedings of the 12th International Conference on Civil Structural and Environmental Engineering Computing. Funchal, Madeira, ISBN 978-190508830-0, (2009).

[7] M. Krejsa, P. Janas, R. Čajka, Using DOProC Method in Structural Reliability Assessment. In: Applied Mechanics and Materials (Volume 300 - 301), pp. 860-869. February 2013.

[8] V. Křivý, P. Marek, K. Kreislová, D. Knotková, Bestimmung der Dickenzuschläge für wetterfesten Stahl im Brückenbau. Stahlbau 82 (8), DOI: 10.1002/stab.2013100342013, 2013. 